\title{
ACERCA DE LA SUPLANTACIÓN LEGISLATIVA DE VOLUNTADES EN LA NEGOCIACIÓN COLECTIVA
}

\author{
Víctor Fernando Manrique López \\ Catedrático de Derecho del Trabajo
}

Sumario: I. Concepto legal. Adhesión-Extensión. II. Configuración doctrinal. III. Procedimiento. IV. Derecho Comparado. a) El caso francés. b) El caso alemán. c) El caso italiano. V. Análisis jurisprudencial.

\section{Concepto legal. Adhesión-Extensión}

El Estatuto de los Trabajadores dice en su artículo 92 lo siguiente en orden a la Adhesión y Extensión de los Convenios Colectivos:

«1. En las respectivas unidades de negociación, las partes legitimadas para negociar podrán adherirse, de común acuerdo, a la totalidad de un convenio colectivo en vigor, siempre que no estuvieran afectados por otro, comunicándolo a la autoridad laboral competente a efectos de registro.

2. El Ministerio de Trabajo y Seguridad Social podrá extender las disposiciones de un convenio colectivo en vigor a determinadas empresas y trabajadores, siempre que exista especial dificultad para la negociación, o se den circunstancias sociales y económicas de notoria importancia en el ámbito afectado.

Para ello será preciso el previo informe de una comisión paritaria formada por representantes de las asociaciones empresariales y organizaciones sindicales más representativas en el ámbito de aplicación».

En relación con tal punto entiende el profesor Galiana Moreno ${ }^{1}$ que en cuanto la adhesión a un convenio colectivo en vigor es una fórmula abreviada de convenir, la ley exige que quienes decidan la adhesión es-

\footnotetext{
1 Comentarios al Estatuto de los Trabajadores, p. 441. Editorial Aranzadi.
} 
tén, en primer término, legitimados para negociar el convenio del que desisten dentro de la respectiva unidad de negociación. Exige, además, que las citadas partes no se encuentren vinculadas por un convenio en vigor, pues, si lo estuvieren, no podrían decidir la adhesión a otro en tanto no se produzca la extinción del primero. Exige, por último, el «común acuerdo» de las partes para la adhesión, lo que no parece deba entenderse por unanimidad de éstas, sino como la concurrencia de «mayoría de cada una de las dos representaciones» que se exige para adoptar acuerdos en la comisión negociadora (art. 89.3).

De esta opinión participa Sempere Navarro ${ }^{2}$ que considera que con estos parámetros, debe precisarse que la adhesión se efectúa a la «totalidad» de un convenio en vigor, no resultando posible adhesiones parciales a determinados aspectos del mismo.

Para Bartolomé Ríos Salmerón ${ }^{3}$ la extensión de convenios es una fórmula para suplir las dificultades de negociación en una determinada unidad negociadora supraempresarial, que se establece como fórmula prioritaria a la alternativa de la regulación por el Gobierno de condiciones de trabajo por rama de actividad a que se refiere la disposición adicional séptima. Para proceder a la misma el Ministerio de Trabajo y Seguridad Social requiere el informe previo de la comisión paritaria a que alude el precepto, formada por representantes de los sindicatos y asociaciones empresariales más representativos en el ámbito en que haya de efectuarse la extensión del correspondiente convenio. Este precepto se encuentra desarrollado por R.D. 572/1982, de 2 de marzo.

\section{Configuración doctrinal}

Tal y como destaca en su obra Derecho del Trabajo el profesor Manuel Alonso $\mathrm{Olea}^{4}$ el ámbito de vigencia inicial del convenio puede ser ampliado a través de los actos de extensión y de los acuerdos o convenios de adhesión a uno previamente celebrado. A través de estos procedimientos de regulación de condiciones de trabajo el convenio experimenta un nuevo proceso de generalización, adicional al resultante del juego de las mayorías para construir la unidad de negociación. El convenio como ley para los afiliados a los entes que pactan pasa sucesivamente a ser ley de grupo primero y ley de la profesión o de la industria, después.

2 Comentarios al Estatuto de los Trabajadores, p. 442. Editorial Aranzadi.

3 Comentarios al Estatuto de los Trabajadores, p. 443. Editorial Aranzadi.

${ }^{4}$ Derecho del Trabajo. Editorial: Servicio Publicaciones Facultad de Derecho. Universidad Complutense de Madrid, p. 749. 
El E.T., artículo 92 prevé y regula tanto la adhesión como la extensión.

En cuanto a lo primero las partes legitimadas para negociar para una determinada unidad de contratación pueden decidir no contratar en detalle, sino adherirse de común acuerdo a un convenio colectivo ya celebrado y en vigor. El acuerdo o pacto de adhesión no es, pues, sino una modalidad singular de convenio colectivo, que como tal ha de ser comunicado a la autoridad laboral, a efectos de registro, publicación y depósito.

La adhesión tiene, sin embargo, para este autor estas limitaciones:

Que no estuvieren afectadas por otro convenio quienes se adhieren para respetar la regla sobre prohibición de concurrencia de convenios del artículo 84.

Que la adhesión sea a la totalidad del convenio colectivo preexistente. Hay que entender, sin embargo que el acuerdo de adhesión, que en realidad, se insiste, no es sino forma de convenio colectivo, con sus mismos requisitos de legitimación negocial, inicial y ampliada y de procedimiento y cuya peculiaridad radica en la determinación de su contenido por apropiación o reenvío material al contenido de otro convenio, tendrá que tener su propio contenido mínimo necesario pues la aplicación pura y simple del convenio preexistente resultará inviable. Por lo demás, la práctica revela la existencia en el seno del convenio colectivo de pactos de adhesión parcial a otro, quizá como norma supletoria.

Dicho autor compartiendo obra y criterio con la profesora Casas Baamonde ${ }^{5}$ viene a establecer en orden a la extensión el que en el derecho comparado es frecuente que se confiera al Estado la facultad de extender lo convenido colectivamente, además de a empresarios y trabajadores no representados por las partes negociadoras para dotar así al convenio de eficacia personal general a los trabajadores y empresarios no comprendidos en la unidad de contratación, normalmente exigiendo determinados requisitos al convenio inicial (un contenido mínimo normativo, que se haya pactado por las asociaciones más representativas, si hay más de una, que la extensión se haga en favor de sectores en que la sindicación es inexistente o débil, etc.).

El Estatuto de los Trabajadores artículo 92.2 según el profesor Barreiro $^{6}$ confía la extensión normalmente de un convenio supraempresarial pero también subsidiariamente de empresa, a una o varias empresas

5 Derecho del Trabajo. Editorial: Servicio Publicaciones Facultad de Derecho. Universidad Complutense de Madrid, p. 749.

${ }^{6}$ Comentarios al Estatuto de los Trabajadores. Editorial Civitas, p. 46. 
o a un sector del mismo o similar ámbito funcional o con características económico-laborales equiparables, al Ministerio de Trabajo o a los órganos correspondientes de las Comunidades Autónomas materialmente competentes, como decisión discrecional. A esta misma dirección parecía dejarse la iniciativa en cuanto a los empresarios y trabajadores a los que el convenio debía ser extendido pero la norma reglamentaria priva a las Administraciones laborales de ella al decir que la iniciativa para la extensión será siempre a instancia de parte, llamando tal el artículo 4, a la legitimada para promover la negociación conforme al Estatuto de los Trabajadores artículo 87, a los sindicatos y asociaciones empresariales implantados en el colectivo carente de convenio o a las representaciones lectivas del Estatuto de los Trabajadores, artículos 62 y 63 .

En cualquier caso, la resolución de extensión sólo se justifica en vista de la especial dificultad para la negociación (dificultad estructural, de déficit de sindicación o representación, y no meramente funcional, Sala), o de las circunstancias sociales y económicas de notoria importancia que la aconsejen en evitación de perjuicios relevantes para trabajadores y empresarios.

El Estatuto de los Trabajadores (disposición adicional 7.a) recomienda que se use antes del procedimiento de extensión que del de dictar normas reglamentarias laborales sectoriales.

La resolución de extensión según Barreiro (obra citada) puede precisar qué extremos del convenio no se extienden por resultar inaplicables al ámbito extendido, especialmente las cláusulas obligacionales (arts. 9.1 DEC). Cabe pues, la extensión parcial como la jurisprudencia ha confirmado. La extensión surte efecto sólo desde la fecha de ejercicio de la iniciativa, por la duración del convenio que se extiende, sin que jueguen las normas del Estatuto de los Trabajadores, artículo 86, sobre prórroga ni denuncia (art. 9.2 y 3 ).

Para el profesor Alonso Olea (obra citada), el acto de extensión no es un convenio colectivo, sino que tiene la naturaleza propia de un acto administrativo, que traslada y aplica a un ámbito distinto el contenido de un convenio preexistente (no crea una norma nueva, sino que se limita a declarar aplicable una ya existente, el convenio extendido en el ámbito en el que inicialmente no lo era, sin alterarlo o modificarlo en su estructura contenido o ámbito de aplicación respecto del que el acto de extensión es un elemento meramente accidental y externo. De ahí el carácter excepcional del procedimiento de extensión, supletorio del derecho constitucional de negociación colectiva, y de ahí también que durante la extensión permanezca abierta la facultad de las partes afectadas de promover la negociación de un convenio propio ante la eventual 
modificación o desaparición de las circunstancias impeditivas de ésta y legitimadoras de aquella.

Debe por último destacarse que no cabe que el Juez de lo social extienda a un ámbito el convenio de otro ante las dificultades de negociación en aquel o ante la petición de una de las partes, deseosa de un ámbito más extenso para el convenio.

Señala el mismo autor que el Estatuto de los Trabajadores no aborda el importante tema de si rige el convenio para los trabajadores y empresarios que durante su vigencia se incorporen a la unidad de contratación. La solución debe ser afirmativa respecto de los trabajadores y también respecto de los empresarios.

A esta última solución había llegado la jurisprudencia durante la vigencia de la Ley de convenios de 1958, bien que con estructura sindical muy distinta: el convenio, dijo la Sentencia de la Sala Cuarta de 21 de junio de 1963, se aplica a todas las empresas tanto encuadradas en aquel momento de celebración del convenio por estar dentro de la unidad de contratación del mismo, como las que con posterioridad se incluyeran en dicho sector.

El ámbito de aplicación de un convenio colectivo como muy bien ha puesto de relieve Montoya Melgar ${ }^{7}$ puede ampliarse a trabajadores y empresarios no incluidos en la correspondiente unidad de negociación, bien mediante la adhesión voluntaria a tal convenio de partes distintas de las que lo celebraron, bien mediante un acto administrativo de extensión del pacto de un ámbito que excede del suyo propio.

Para este autor (obra citada) el acto de adhesión a un convenio preexistente es, en rigor, una modalidad peculiar de la negociación colectiva. En efecto, los entes legitimados para concertar un pacto colectivo en una determinada unidad de negociación pueden preferir a la negociación de un convenio el procedimiento más expeditivo y menos costoso de adherirse a otro ya existente; la voluntad negociadora tiene por objeto, precisamente, asumir como propio el convenio concertado por partes ajenas. De ahí que sea necesario que el acto de adhesión se formule «de común acuerdo» (art. 92.1 E.T.) por las partes legitimadas para convenir.

Ese «común acuerdo», que bien podría denominarse convenio colectivo por adhesión, sustituye, con el puro y simple acto de aceptación en bloque de un convenio ajeno, al procedimiento de deliberación y acuerdo fijado como supuesto general en el E.T. El artículo 92.1 confirme que, en efecto, la adhesión ha de producirse respecto de «la totali-

\footnotetext{
7 Derecho del Trabajo. Editorial: Tecnos, p. 183.
} 
dad de un convenio colectivo en vigor», no caben las adhesiones parciales (sólo a una cláusula o a un grupo de cláusulas del convenio).

Aunque parece una exigencia superflua, el mismo artículo 92.1 E.T. condiciona según el propio Montoya (obra citada) la posibilidad de la adhesión al hecho de que la correspondiente unidad no esté afectada ya por un convenio colectivo.

El artículo 92.1 completa su regulación exigiendo que el acto de adhesión sea comunicado (obviamente, por escrito) a la Administración laboral «a efectos de registro». A diferencia de lo que ocurre con los convenios en sentido estricto, el artículo 92.1 no ordena ni el depósito administrativo habitual del acto de adhesión ni su publicación en el Boletín Oficial que corresponda (del Estado o de la Comunidad Autónoma o provincia); sin embargo, parece razonable extender estas exigencias a los actos de adhesión, como en efecto lo hace el R.D. 1.040/1981 en cuanto al acto de depósito, y como, respecto de la publicación oficial, se deduce analógicamente del R.D. 572/1982 (infra, $2 .^{\circ}$ ).

En orden a la extensión, Montoya (obra citada) indica que el acto administrativo de extensión del convenio colectivo no tiene en nuestro vigente Derecho la misma significación que en otros Ordenamientos, en los que la extensión del pacto colectivo es el mecanismo utilizado para dotar de eficacia «erga omnes» o general a un convenio de efectos limitados. Siendo así que el E.T. consagra el convenio de eficacia general en todo caso, el acto de extensión ha de tener finalidad distinta de la de alcanzar una eficacia que ya existe por principio; tal finalidad no es otra que la de llenar un vacío normativo (ausencia de convenio en un determinado ámbito) mediante la aplicación, por decisión administrativa, de las normas de un convenio existente.

El R.D. 572/1982, de 5.3, que desarrolla el artículo 92.2 E.T. sobre extinción de convenios, puntualiza, en su misma exposición de motivos, «la naturaleza excepcional del mecanismo de extensión», en la medida en que el principio de autonomía de la voluntad colectiva es sustituido por la intervención pública.

La extensión es, pues, objeto de una decisión del Ministerio de Trabajo y Seguridad Social, y parecería referida, como ocurre en la adhesión, al convenio en su totalidad; el artículo 92.2 E.T. no dice, en efecto, que el Ministerio pueda extender disposiciones de un convenio, son las disposiciones (esto es, todas) de tal convenio. Sin embargo, el R.D. $572 / 1982$ adopta otro criterio interpretativo al disponer que «la resolución que se dicte decidirá en su caso los extremos del Convenio inaplicables» (art. 9.1).

Añade este autor que la inexistencia de convenio en un determinado ámbito es causa necesaria pero no suficiente para que se dicte un 
acto de extensión. El citado artículo 92.2 exige además unos requisitos de fondo y forma: a) requisito de fondo es que exista «especial dificultad para la negociación» o que la extensión venga exigida por «circunstancias sociales y económicas de notoria importancia en el ámbito afectado», dificultad y circunstancias cuya apreciación compete al Ministerio; b) requisito formal es que al acto de extensión preceda necesariamente el informe de una comisión paritaria formada por representantes de los sindicatos y asociaciones patronales con mayor representatividad en el ámbito afectado. Aunque nada digan al respecto el E.T. y el R.D. 572/1982, dicho informe habrá de versar sobre las razones de fondo de la posible extensión, pronunciándose sobre su oportunidad. En todo caso, el trámite legal queda cumplido con la mera formulación del informe, que carece de efectos vinculantes.

El procedimiento de extensión se inicia necesariamente a instancia de parte (los recelos anti-intervencionistas del R.D. 572/1982 le llevan a una interpretación desviada del artículo 92.2 E.T., vedando la iniciación de oficio). El ministerio ha de requerir a las organizaciones más representativas en el ámbito al que haya de extenderse el convenio para que designen la Comisión Paritaria que ha de informar la extensión (art. 6.1 R.D. 527/1982). Emitido este informe y expedido el certificado del registro de Convenios acreditativo de no existir convenio en el ámbito en cuestión, y eventualmente el de la Comisión Paritaria que ha de informar la extensión (art. 6.1 R.D. 572/1982). Emitido este informe y expedido el certificado del Registro de Convenios acreditativo de no existir convenio en el ámbito en cuestión, y eventualmente el de la Comisión Paritaria del Convenio que ha de ser objeto de extensión, el Ministerio resuelve.

Montoya (obra citada) hace una última indicación sobre el régimen legal del acto de extensión del pacto colectivo indicando que en ausencia de convenio colectivo en un determinado ámbito, el Ministerio deberá acudir, como «procedimiento prioritario», a la técnica de la extensión; sólo en defecto de ésta — supuesto difícil de concebir, pues ello equivaldría a admitir que no existen motivos serios para extender el convenio- podrá el Ministerio proponer al Gobierno que dicte una norma reglamentaria «por rama de actividad» (disp. adic. 7. ${ }^{\mathrm{a}}$, E.T.).

La adhesión y extensión de los convenios colectivos ha sido igualmente analizada por el profesor Sala Franco ${ }^{8}$ que indica que los convenios colectivos pueden ver ampliados sus ámbitos de aplicación, bien a través de un acuerdo de adhesión, bien a través de un acto de extensión.

8 La Negociacion Colectiva y los Convenios Colectivos. Ediciones Deusto, p. 39. 
En orden a la adhesión destaca este autor que el artículo 92.1 del Estatuto de los Trabajadores prevé que «en las respectivas unidades de negociación, las partes legitimadas para negociar podrán adherirse, de común acuerdo, a la totalidad de un convenio colectivo en vigor, siempre que no estuvieran afectadas por otro, comunicándolo a la autoridad laboral competente a efectos de registro».

Así pues, para proceder a la adhesión a un convenio colectivo en una determinada unidad de negociación se precisa en todo caso el acuerdo entre las partes legitimadas para negociar en ese ámbito, según los artículos 87 y 88 del Estatuto de los Trabajadores y según las reglas del artículo 89 del Estatuto de los Trabajadores para tomar decisiones. Rigen, consiguientemente, las mismas reglas que para negociar un convenio colectivo cuyo contenido consiste en adherirse a otro ya existente.

Siguiendo el magnífico trabajo elaborado por el Magistrado del Tribunal Supremo Iglesias Cabero ${ }^{9}$ cabe señalar que la ley establece tres condicionantes para la validez de la adhesión:

1. Que la adhesión se refiera a la totalidad del convenio colectivo en vigor. No caben, en consecuencia, adhesiones parciales; si bien, dada la libertad negocial que establece el artículo $85.1 \mathrm{del}$ Estatuto de los Trabajadores, nada impide que se negocie la adhesión a un convenio parcial.

De otra parte, la ley exige que el convenio esté en vigor, lo que implica que las vicisitudes de ese convenio afectarán al colectivo adherido. Así, por ejemplo, si el convenio al que se adhieren resultase nulo en todo o en parte, nulo resultaría también el convenio de adhesión.

2. La ley exige que las unidades de negociación que quieran adherirse no estén ya «afectadas por otro» convenio. En realidad, no se hace sino repetir la regla general de la no concurrencia de convenios del artículo 84 del Estatuto de los Trabajadores.

3. Por último, será preceptiva la comunicación a la autoridad laboral competente «a efectos de registro»; exigencia legal a la que habrían de añadirse el depósito y la publicación.

Así pues, se trata de un verdadero convenio colectivo cuya única diferencia reside en que en vez de desarrollar un convenio se limita a remitirse al contenido de otro convenio al que se adhiere. Por esta razón, se exigen los mismos requisitos de procedimiento que para la negociación de un convenio colectivo ordinario.

9 Negociación Colectiva. Editorial Colex, p. 205. 
Por lo que se refiere a la extensión de Convenios, Sala (obra citada) considera que el artículo 92.2 del Estatuto de los Trabajadores, desarrollado por el Real Decreto 572/1982, de 5 de marzo, faculta al Ministerio de Trabajo para extender las disposiciones de un convenio colectivo en vigor a empresas y trabajadores no afectados inicialmente por él en determinados casos, con la finalidad de cubrir un vacío de negociación existente en ese ámbito de aplicación.

Se trata pues, de extender el ámbito territorial y/o funcional de un convenio colectivo, siendo posible en este sentido, tanto la extensión de convenios a concretas empresas como a sectores o subsectores profesionales de actividad, siempre que el colectivo afectado por la extensión pertenezca «al mismo o similar ámbito funcional o con características económico-laborales equiparables» (art. 2 del Real Decreto 572/1982).

El Estatuto de los Trabajadores señala dos posibles motivaciones del acto de extensión:

1. La existencia de una especial dificultad para la negociación.

2. La existencia de circunstancias sociales y económicas de notoria importancia en el ámbito afectado.

La primera de las motivaciones resulta identificable con existencia de dificultades estructurales, esto es, ausencia de organizaciones sindicales o empresariales que imposibiliten la negociación de un convenio según los artículos 87 y 88 del Estatuto de los Trabajadores (art. 3.1 del Real Decreto 572/1982) «circunstancias sociales o económicas de notoria importancia que aconsejen la extensión de un convenio vigente a otras empresas o trabajadores en evitación de perjuicios relevantes para unas y otros».

En relación al alcance de la extensión administrativa de un convenio, el Profesor Sala (obra citada) señala que convendría hacer dos matizaciones de interés práctico:

1. Dado el carácter heterónomo del procedimiento de extensión, pese al informe previo, de los representantes empresariales y sindicales, no parece que el acto de extensión se refiera al contenido obligacional del convenio - tan sólo al contenido normativo- ya que ello atentaría contra la autonomía colectiva de las partes y contra el derecho de huelga durante la aplicación de un convenio colectivo, por vía de extensión no habrá deber de paz, pudiendo ir a la huelga los trabajadores lícitamente para negociar un convenio colectivo propio (arts. 9.1 y 10 del Real Decreto 572/1982). 
2. Si bien existen dudas sobre la posibilidad de una extensión parcial de un convenio colectivo, la jurisprudencia ha confirmado tal posibilidad (STS Sala 3. ${ }^{a}$ del 13 de abril de 1982: «En la extensión no se hace expresa exigencia de la integridad o totalidad del convenio»).

\section{Procedimiento}

El Real Decreto 572/1982 concreta el procedimiento de extensión sumariamente descrito en el artículo 92.2 del Estatuto de los Trabajadores y así:

1. La iniciativa será siempre a instancia de parte (art. 3.2).

2. Por «parte» hay que entender:

a) Quienes se hallen legitimados para promover la negociación conforme al artículo 87 del Estatuto de los Trabajadores o, en su defecto, cubran las previsiones determinadas en la disposición adicional sexta del Estatuto de los Trabajadores.

b) Las organizaciones sindicales y asociaciones empresariales con implantación en colectivos carentes de convenio propio y no vinculadas por aquél cuya extensión se pretende o los delegados de personal y comités de empresa (art. 4).

3. La solicitud habrá de hacerse por escrito, dirigida al Ministerio de Trabajo y Seguridad Social y fundada en alguno de los motivos señalados, debiendo acompañarse la documentación acreditativa de reunir los requisitos de legitimidad para iniciar el procedimiento y de los motivos alegados (art. 5).

4. A requerimiento del Ministerio de Trabajo y en el plazo de 10 días a partir del mismo, se constituirá una comisión paritaria formada por representantes de las organizaciones sindicales y empresariales que tengan capacidad para iniciar el procedimiento de extensión o por los miembros del comité de empresa o delegados de personal o representantes de las centrales sindicales promotoras de la extensión cuando afecta a una empresa (art. 6).

5. Esta comisión paritaria habrá de informar sobre la extensión del convenio solicitada en el plazo de 15 días desde su constitución, estimándose el silencio de la comisión como informe favorable a la extensión (art. 7.1).

6. Cuando no se hubiese constituido la comisión paritaria en el indicado plazo de 10 días, el Ministerio de Trabajo y Seguridad Social requerirá a las organizaciones y asociaciones correspon- 
dientes a que en el plazo de 15 días emitan los pertinentes informes, estimándose igualmente favorable el silencio de los mismos (art. 7.2).

7. Deberá ser oída también preceptivamente la Comisión Consultiva Nacional de los convenios colectivos en los casos de extensión de ámbito superior al de Comunidad Autónoma (Real Decreto 2.976/1983, de 9 de noviembre).

8. La extensión surtirá efectos desde la fecha de presentación de la solicitud de extensión (art. 9.2).

9. El acto de extensión estará sometido a idénticas exigencias de registro, depósito y publicación que los convenios colectivos (art. 11).

Para el mismo autor el acto de extensión es un acto reglamentario y no convencional, lo que según Sala implica las consecuencias siguientes:

1. La posibilidad de ser recurrido administrativamente y ante la jurisdicción contencioso-administrativa.

2. La desvinculación del convenio extinguido respecto al ámbito al que se extendió. Así los efectos de la prórroga anula y denuncia a que se refiere el artículo 86.2 y 3 del Estatuto de los Trabajadores no afectarán a quienes se aplique por extensión un convenio colectivo (art. 9.3 del Real Decreto 572/1982). No obstante, la duración de la extensión coincidirá con la del convenio extendido (art. 9.2 del Real Decreto 572/1982).

3. La posibilidad de negociar un convenio colectivo vigente el acto de extensión cuando desaparezcan las causas que lo motivaron (art. 10 del Real Decreto 572/1982) no rigiendo en este caso el principio de no concurrencia entre convenios colectivos del artículo 84 del Estatuto de los Trabajadores.

En su obra Lecciones sobre Convenios Colectivos, Derecho de Huelga y Cierre Patronal el profesor Carlos Molero Manglano ${ }^{10}$ lo destaca:

En cuanto a la Adhesión entiende que: Prevista esta figura con un carácter de normalidad, en contraste con la excepcionalidad con que se concibe la extensión, podríamos decir que los requisitos que exige el 92.1 para proceder válidamente a la adhesión son los siguientes:

10 Lecciones sobre Convenios Colectivos, Derecho de Huelga y Cierre Patronal. Editorial: Ediciones ICAI, p. 61. 
1) Que se decida por las partes legitimadas para negociar en la respectiva unidad de negociación y en relación con cual sea el ámbito al que va a aplicarse el convenio al que quieran adherirse.

2) Que la decisión se adopte de común acuerdo, lo que es tanto como remitirse a las reglas sobre los acuerdos de la Comisión Negociadora del 89.3 y a la propia composición de ésta conforme al 88.

3) Que la adhesión sea respecto a la totalidad de otro convenio colectivo, lo que supone la totalidad del contenido normativo y del obligacional.

4) Que el convenio al que pretendan adherirse esté en vigor, con lo que se descarta absolutamente la posibilidad de adhesión a un texto sustituido ya por un nuevo acuerdo y probablemente también a un texto ya denunciado cuyas cláusulas obligacionales han perdido ya vigencia y las normativas mantienen unas puramente provisional.

5) Que la unidad de negociación que pretende adherirse no esté afectada por otro convenio, de ámbito lógicamente igual o superior.

6) Comunicación a la autoridad laboral competente a efectos de registro, requisito éste cuya omisión, teniendo en cuenta que si el convenio al que se adhieren ya está en vigor estará debidamente publicado, probablemente no tendría más consecuencia que la posible responsabilidad de las partes negociadoras en el orden administrativo.

Sobre la posibilidad de un acuerdo de adhesión pueden las organizaciones sindicales y asociaciones más representativas, órganos o entidades sindicales o empresariales con interés legítimo así como cualquier autoridad laboral o jurisdiccional competentes, formular consultas a la Comisión Consultiva Nacional de Convenios colectivos, creada en la disposición final 8. ${ }^{a}$ del E.T. y regulada por el R.D. 2.976/83, de 9 de noviembre.

Bajo el criterio de excepcionalidad al que ya se refiere Molero Manglano (obra citada), prevé el artículo 92.2 la posibilidad de extensión por el Ministerio de Trabajo, de conformidad al siguiente procedimiento establecido por el R.D. 572/82, de 5 de marzo, desarrollador del citado artículo del Estatuto de los Trabajadores pormenorizado en los siguientes apartados de acuerdo con lo que expresamente expone dicho autor:

1) La resolución que se dicte decidirá en su caso los extremos del Convenio aplicables. 
2) Vigencia de dicho convenio a extender, en los términos señalados para la adhesión.

3) Extensión a empresas y trabajadores que no tienen por qué coincidir con el ámbito de aplicación de un convenio previo de ámbito superior al de la empresa o subsidiariamente, un convenio de empresa si no existiese aquél.

4) Especial dificultad para la negociación por inexistencia de partes legitimadas para negociar conforme el artículo 87 del E.T., o incluso sin ella, circunstancias sociales y económicas de notoria importancia. Esta última alternativa resulta difícil de concebir si no se da previamente la especial dificultad para negociar, pues no es concebible ni constitucionalmente admisible que el poder ejecutivo usurpara la libertad de negociación sólo por la importancia social y económica de un sector, aunque no se haya manifestado ninguna dificultad especial para iniciar o culminar la negociación del convenio.

5) La iniciativa será siempre a instancia de parte, pudiendo solicitar la extensión quienes estén legitimados conforme al artículo 87 del E.T. o los que, al menos, cubran las previsiones de la disposición adicional 6.a del propio texto legal. Asimismo las organizaciones sindicales y asociaciones empresariales con implantación o los representantes a que se refieren los artículos 62 y 63 del E.T.

6) Informe previo de una Comisión paritaria de representantes empresariales y sindicales, más representativos en el ámbito correspondiente, conforme a la Ley Orgánica de Libertad Sindical. Debe tenerse en cuenta que el informe de tal Comisión Paritaria no parece, aquí, en cambio, que deba contar con el común acuerdo de las partes y que el único requisito a respetar por el Ministerio de Trabajo es el de su evacuación previa al acto de extensión, trámite que también se cumple, si transcurridos 15 días ni se ha emitido informe, por entender entonces, que el criterio es favorable a la extensión. Siendo también preceptiva la consulta a la Comisión Consultiva Nacional de Convenios Colectivos, pudiéndose también recabar informe en la Comisión Paritaria del Convenio cuya extensión se solicita, no teniendo ninguno de los informes carácter vinculante.

7) Los efectos del Convenio extendido se producirán a partir de la fecha de la solicitud formal. Su duración será la prevista en el propio Convenio y se podrá promover en el caso de modificación o desaparición de las circunstancias que motivaron la extensión. 
Tal y como ciertamente ha señalado el profesor de la Villa11, la eficacia personal de un Convenio se puede ver afectada, en ocasiones, por las dificultades que para la negociación colectiva existan en determinadas empresas y aun sectores de la actividad económica, y que, ajenas, a aquél, buscan sin embargo en un convenio ya negociado y vigente solución transitoria a sus problemas negociales. La adhesión, y la extensión de un Convenio en vigor supondrá, así, la incorporación al ordenamiento jurídico de expedientes (autónomos y heterónomos, respectivamente) de solución para situaciones en las que la negociación colectiva deviene difícil o, simplemente, en las que las partes prefieren evitar renegociar lo que a su juicio ha sido ya favorablemente resuelto por un determinado convenio.

Para García Becedas ${ }^{12}$ el carácter común de ambas figuras será, en consecuencia, la ampliación del ámbito personal de aplicación del Convenio a sujetos que, originariamente, se hallan excluidos — por no representados- del mismo. No se trata por tanto de dotar de eficacia general a un convenio de aplicación limitada, sino de extender la eficacia general de un determinado convenio a colectivos de trabajadores y empleadores situados al margen de las unidades de negociación sobre las que el convenio se proyecta.

En contraste con la situación comparada, donde el mecanismo de la adhesión (y de la extensión) se presente como fórmula habitual para ampliar el ámbito de aplicación de convenios de eficacia limitada, de modo que aquél opera en una unidad de negociación dada, la eficacia erga omnes que posee el Convenio en nuestro ordenamiento jurídico obliga a practicar la adhesión desde unidades distintas de negociación y, por ello, este procedimiento ha arrastrado una vida lánguida desde su reconocimiento legal por la LCC 73 (art. 17).

García Perrote ${ }^{13}$ explica que en su opinión el Estatuto de los Trabajadores reconoce y regula la adhesión a un convenio en vigor, estableciendo en su artículo 92,1 los requisitos para efectuarla (STCT 26 mayo. 81, Ar. 3697). Sujetos capacitados para acordar la adhesión serán, en primer lugar, «las partes legitimadas para negociar» en las «respectivas unidades de negociación», es decir, aquellas que reúnan la capacidad y legitimación negociales exigidas por los artículos 87 y 88 del Estatuto

11 Instituciones de Derecho del Trabajo. Editorial: Centro de Estudios Universitarios. Ramón Areces, p. 120.

12 Instituciones de Derecho del Trabajo. Editorial: Centro de Estudios Universitarios. Ramón Areces, p. 120.

13 Instituciones de Derecho del Trabajo. Editorial: Centro de Estudios Universitarios. Ramón Areces, p. 122. 
de los Trabajadores para las unidades susceptibles de ser reguladas por Convenio. Asimismo, la decisión de adherirse a un convenio ha de ser adoptada por las partes negociadoras de «común acuerdo», no siendo posibles por tanto adhesiones unilaterales. El Estatuto de los Trabajadores aclara así las dudas surgidas al respecto en la interpretación del derogado artículo 17 de la Ley de Convenios Colectivos de 1973, a cuyo amparo - y a pesar del tenor literal del artículo 27 del Reglamento de dicha ley, que exigía acuerdo adoptado en «reunión reglamentariamente celebrada al efecto»- fueron homologadas adhesiones efectuadas por sólo una de las partes.

Para el Profesor de la Villa (obra citada, p. 122), la adhesión ha de venir referida, de otra parte, a «la totalidad de un convenio colectivo en vigor», no siendo en principio posible acordar adhesiones parciales. En este punto el Estatuto de los Trabajadores insiste por tanto en una antigua exigencia de la Ley de Convenios Colectivos de 1973, y que, introducida en la Comisión de Trabajo del Congreso mediante enmienda de Coalición Democrática, es objeto de críticas para este autor que base las mismas, en primer término, en la medida en que el acuerdo de adhesión deberá reunir su propio contenido mínimo ex art. 85,2 LET, y también en la medida que los ámbitos (al menos personales) de éste habrán de ser necesariamente distintos, ex art. 92,1 LET, de los contemplados por el Convenio objeto de adhesión. No cabe en modo alguno adherirse a la «totalidad», a salvo de entender esta expresión como excluyente de los contenidos mínimos de todo convenio. En segundo lugar añade este autor que pugna con la autonomía colectiva y la libertad de acción de las partes, obligar a éstas a adherirse también a las cláusulas obligacionales que los firmantes del convenio negociaron e incorporaron atendiendo a una situación objetivamente distinta; tanto, que una permite un convenio y la otra exige una pura y simple adhesión. Concluyendo: la adhesión deberá ser efectuada a la totalidad pero de la parte normativa del Convenio, precisando incorporar el acuerdo de adhesión su propio contenido mínimo y, en su caso, las estipulaciones obligatorias que los adherentes tengan a bien negociar y establecer; aunque, si lo estiman oportuno, puedan remitirse expresamente a cuantas deseen de las incluidas en el Convenio objeto de la adhesión.

Debe añadirse que la configuración técnica del acuerdo de adhesión como un auténtico convenio colectivo o convenio de adhesión, debe igualmente permitir que la «libertad de contratación» de las partes negociadoras sujete la adhesión a condición o término según indica Alonso Olea (obra citada p. 750).

Para García Becedas (obra citada p. 123), la extensión de un Convenio se halla condicionada a la concurrencia de algunas de estas dos 
circunstancias habilitantes: de una parte, que «exista especial dificultad para la negociación» colectiva; o, de otra, que «se den circunstancias sociales y económicas de notoria importancia en el ámbito afectado» (art. 92,2 párrafo $1 .^{\circ}$ LET). En relación con la primera de ellas, dicho autor señala lo siguiente que debe expresarse separadamente:

- Sin diferencia con lo establecido por el artículo 19 LCC 73, que es antecedente inmediato, es preciso también ahora que tal circunstancia quede acreditada en el expediente administrativo elaborado al efecto (art. 5,a, R.D. 572/82).

- La dificultad para la negociación colectiva debe relacionarse, exclusivamente (art. 3, R.D. 572/82), con la existencia de peculiaridades de carácter estructural (dispersión de los trabajadores, elevada movilidad geográfica, intensidad excepcional del trabajo de temporada, etc.) o coyuntural (inexistencia de sujetos legitimados para negociar, imposibilidad de constituir la comisión negociadora, etc.) en la empresa o sector de que se trate, pero en modo alguno con la existencia de una situación conflictual conducida por las partes a través del recurso a medidas de autotutela; lo contrario supondría atentar desde la Administración a la autonomía colectiva, o, pura y simplemente, conculcar el derecho de huelga (STCT 21 ab. 83, rec. 158/83). La mención a «otras causas que impidan el libre desarrollo de la negociación», contenida en el art. 3,1,a) del R.D. 572/82, excede sin duda las previsiones estatutarias, y debe reputarse, por ello, ilegal.

En relación con las segunda de esas circunstancias habilitantes, debe anotarse, asimismo, que la expresión legal remite, en interpretación literal, a sectores económicos especialmente deprimidos, frente a los cuales el Estado reacciona en clave promocional ex art. 9,2 CE.

Para García Perrote (obra citada p. 122), el ámbito de la extensión administrativa del Convenio plantea el segundo problema a despejar. Porque el tenor del artículo 92,2 párrafo $1 .^{\circ}$ LET, en virtud del cual aquélla podrá ser realizada a «determinadas empresas y trabajadores» parece en principio indicar que queda excluida toda posibilidad de extensión sobre grupos profesionales o sectores de la actividad económica. Sin embargo, si se repara en que la disposición adicional $1 .^{\mathrm{a}}$ LET remite a «sectores económicos de la producción y demarcaciones territoriales» a efectos de la reglamentación administrativa de las condiciones de trabajo, y se observa que esa excepcional facultad cede ante la posibilidad de proceder a la extensión de un Convenio, habrá de concluirse - y así lo confirma el artículo 2, R.D. 572/82- que, necesariamente, los ámbi- 
tos territorial y/o funcional de ambos sistemas deberán coincidir formalmente. Por tanto, lo que exige el artículo 92,2 párrafo $1 .^{\circ}$ LET es que la extensión se produzca nominativamente, concretándose o identificándose expresamente qué empresas y qué trabajadores quedan afectadas por el convenio extendido, con independencia de que se integran o no en un sector de la producción o en una demarcación territorial; decisión ésta, por lo demás, que no puede quedar al arbitrio de la Administración sino que exigirá la existencia de una relación directa de causa (circunstancias habilitantes) a efecto (ámbito de la extensión realizada).

El profesor de la Villa (obra citada p. 120) se plantea la cuestión relativa a si acaso la Autoridad administrativa podría extender sólo parcialmente un determinado convenio, sólo algunas «disposiciones de un convenio colectivo» expresión legal que contrasta con la formulada respecto de la adhesión, donde se explicita que ha de serlo «a la totalidad». Para este autor la respuesta debe ser negativa, de una parte porque la dicción disposiciones remite técnicamente a la parte normativa del convenio, en puridad la única extensible como ocurría — si bien allí atenuadamente por tratarse de un procedimiento autónomo- en materia de adhesión; y, de otra, porque lo contrario podría permitir una actividad discrecional adicional de la Administración que, sobre discriminatoria, pugnaría con el papel secundario y limitado atribuido por la LET a la extensión (Sala). En este punto el R.D. 572/82 vuelve a adaptarse, sin embargo, del recto desarrollo de la LET, en cuanto que — con ambigua redacción- establece en su artículo 9,1 que «la resolución que se dicte resolverá en su caso los extremos del convenio inaplicables, con especial consideración de las cláusulas obligacionales». Entiende de la Villa que si ello significa que cabe extender sólo una parte del contenido normativo ( «extremos del convenio inaplicables») o que cabe extender también pactos obligacionales («con especial consideración de las cláusulas convencionales») habrá de concluirse que el R.D. $572 / 82$ incurre, de nuevo, en ilegalidad manifiesta.

García Becedas (obra citada p. 123), en cuanto a la cuestión relativa a qué debe entenderse por «organizaciones sindicales y asociaciones empresariales más representativas en el ámbito al que haya de extenderse el Convenio», señala que desde luego no podrá estarse al contenido en el artículo 88 LET, precisamente por venir la extensión a su modo que posiblemente bastará con que sindicatos y asociaciones patronales gocen de implantación en el ámbito de aplicación correspondiente, al margen de que ésta sea de «tono menor» y con independencia de que la pudieran poseer a niveles superiores. El criterio contenido en el artículo 4, párrafo $2 .^{\circ}$ R.D. 572/82, a efectos de capacidad para solicitar la extensión parece así el más adecuado a esta finalidad. 
El profesor Palomeque ${ }^{14}$ es también de la misma opinión entendiendo que el ámbito de vigencia originario del convenio colectivo puede ser ampliado a través de una doble vía o procedimiento: los acuerdos de adhesión y los actos administrativos de extensión de un convenio previamente celebrado, destacando que las partes legitimadas para negociar un convenio colectivo (art. 87 E.T.) podrán adherirse, de común acuerdo, «a la totalidad de un convenio colectivo en vigor, siempre que no estuvieran afectados por otro», sin más que comunicarlo a la autoridad laboral competente a efectos de registro (art. 92.1 E.T.). El acuerdo de adhesión se configura propiamente como una forma o modalidad de convenio colectivo (convenio colectivo por adhesión), al igual que el Ministerio de Trabajo y Seguridad Social, o los órganos correspondientes de las Comunidades Autónomas que hayan recibido competencia en la materia, podrá extender «las disposiciones de un convenio colectivo en vigor a determinadas empresas y trabajadores» (art. 92.2 E.T.), con arreglo al régimen jurídico anteriormente establecido.

Para este autor (obra citada p. 261), el acto de extensión del convenio, preferido legislativamente frente a la regulación administrativa sectorial de condiciones de trabajo (disp. adicional 1. ${ }^{a}$ E.T.), no es ya un convenio colectivo, «sino que tiene la naturaleza propia de una norma estatal que asume y hace suyo el contenido de un convenio (...) es un reglamento administrativo, cuyo contenido queda integrado per relationem a través de las disposiciones establecidas en el convenio» (STC, Pleno, 17/1986, de 4-2, 3).

El profesor V. Russomano ${ }^{15}$ destaca en tal sentido que el convenio colectivo amplía así y de esta manera el área del Derecho del Trabajo, al mismo tiempo que la invade en todas las direcciones. Las leyes laborales en los países industrializados dice este tratadista, pierden gran parte de la importancia que antes les era atribuida. Pasan a ser solamente un mínimum de garantía, o como acostumbramos a decir, el límite inferior de los derechos atribuidos a los trabajadores.

\section{Derecho Comparado}

A nivel internacional conviene mencionar la situación en Francia en donde cuando no exista convenio colectivo nacional, regional o local (art. L. 132-3, párrafo 1), aquéllos pueden determinar el conjunto

\footnotetext{
14 Derecho Sindical Español. Editorial: Tecnos, p. 260.

15 Principios Generales de Derecho Sindical. Editorial: Instituto de Estudios Políticos. p. 216.
} 
de las condiciones de trabajo y beneficios sociales, inspirándose para ello señaladamente en las disposiciones previstas por el artículo L. 133-3. Pueden también fijar, cuando las partes están de acuerdo con ello, las tasas de los salarios efectivos, así como las de los complementos del salario (art. L 132-3, párrafo 1).

\section{a) El caso francés}

Según se ocupa de destacar el profesor Jean-Claude Javillier ${ }^{16}$, en lo que puede denominarse la experiencia francesa, debe tenerse en cuenta que cuando existe un convenio colectivo nacional, regional o local, los convenios de empresa o de centro pueden entonces adoptar las disposiciones de dichos convenios a las condiciones particulares de las empresas o centros considerados. Por otra parte, pueden fijar la tasa de los salarios efectivos y la de los complementos del salario, así como adoptar disposiciones nuevas y cláusulas más favorables para los trabajadores (art. L. 132-3, párrafo 2).

En el ámbito de este ordenamiento jurídico es posible celebrar, en el ámbito de la empresa, un convenio colectivo ordinario, no limitado en su objeto, y aplicable al conjunto de los centros de esta empresa, como es posible situar un convenio en el ámbito de un centro distinto. El texto hace también posible la celebración de un convenio común a un grupo de empresas.

Se pueden distinguir, en cuanto a su contenido, los convenios nacionales de los convenios regionales o locales.

Los convenios nacionales deben contener cláusulas obligatorias previstas por el artículo L. 133-3: libre ejercicio del derecho sindical y libertad de opinión de los trabajadores, elementos de salarios (modalidades de aplicación del principio «a trabajo igual, salario igual», etc.), plazo de preaviso, financiación de las obras sociales del comité de empresa, etc. Entre las cláusulas facultativas: condiciones particulares de trabajo (horas extraordinarias, trabajos en domingos, nocturnos, etc.), primas de antigüedad y de asiduidad, indemnizaciones por desplazamientos, procedimiento de composición de conflictos, régimen de retiro complementario, etc. Puede también ser derogado por la reglamentación de la ordenación y el reparto de las horas de trabajo (art. 133-5).

Los convenios regionales o locales, si existe un convenio nacional en la rama de actividad interesada, adaptan las disposiciones de éste a las condiciones particulares de trabajo, de la región o de la localidad

16 Derecho del Trabajo. Editorial: Instituto de Estudios Laborales y de la Seguridad Social, p. 577. 
considerada (art. L. 133-9, párrafo 1). Pueden también contener disposiciones nuevas y cláusulas más favorables a los trabajadores (Ibid., párrafo 2).

En el caso contrario - si no existe convenio nacional- los convenios regionales o locales deben contener las cláusulas obligatorias previstas por el artículo L. 133-3, adaptadas, cuando se considere necesario en razón al nivel de negociación, al ámbito regional o local. El Ministro de Trabajo puede, en efecto, en ciertas condiciones extender un convenio colectivo que no contuviera todas las cláusulas obligatorias enumeradas en el artículo L. 133-3 (art. L. 133-12-4. ${ }^{\circ}$ ).

En orden a la extensión del Convenio colectivo la Legislación Francesa nos aporta los siguientes datos:

El Convenio colectivo, para ser extendido, debe ser celebrado y negociado en ciertas condiciones, y con arreglo a un procedimiento determinado, de donde se derivan importantes efectos.

\section{Celebración y negociación del convenio}

Con un contenido en parte obligatorio, el Convenio se negocia en el seno de una comisión mixta paritaria compuesta por representantes de las organizaciones sindicales de empleadores y de trabajadores más representativas (art. L. 133-1 párrafo 1). La comisión mixta se reúne habitualmente bajo la presidencia de un representante del Ministro de Trabajo. El número de representantes de las organizaciones sindicales no se determina por la ley. Estos últimos pueden hacerse asistir de suplentes o de consejeros técnicos.

Este procedimiento se aplica a los acuerdos nacionales interprofesionales (art. L. 133-1, párrafo 1, in fine).

El Ministro de Trabajo o su representante puede, a petición de una de las organizaciones sindicales nacionales de empleadores o de trabajadores interesados más representativas, o por propia iniciativa, reunir una comisión mixta para la celebración de un convenio colectivo de trabajo que tenga por objeto regular las relaciones entre empleadores y trabajadores de una rama de actividad (art. L. 133-7).

Cuando dos organizaciones, como mínimo, así lo solicitan, el ministro o su representante debe provocar la reunión de la comisión mixta (art. L. 133-8).

Si una organización no envía representante, se procede a una nueva convocatoria en el plazo de un mes (art. R. 133-3). Ante la ausencia de participación sin motivo legítimo, se remite un informe al Fiscal de la República (art. R. 153-3, párrafo 1). Hay infracción penal (art. R. 153-3, párrafo 2). 
El ámbito de aplicación territorial del convenio puede ser nacional, regional o local. Los convenios regionales y locales pueden ser extendidos, incluso en caso de inexistencia de convenio nacional (art. L. 133-6, y art. 133-9).

El campo de aplicación profesional del Convenio susceptible de extensión es el de la rama de actividad (art. L. 133-1, párrafo 1-L 133-6, párrafo 1). No obstante, cuando se trata de un acuerdo nacional profesional o interprofesional, con un contenido determinado relativo a las condiciones de trabajo o a los beneficios sociales, o señaladamente a las condiciones de empleo, y celebrado entre las organizaciones sindicales de empleadores y de trabajadores más representativas a nivel nacional, profesional o interprofesional, una resolución del Ministro de Trabajo, a condición de que el informe motivado favorable de la comisión superior de convenios colectivos haya sido emitido sin oposición, puede extender este acuerdo (art. 133-12, párrafo $1,6 .^{\circ}$ ).

$\mathrm{Si}$ el convenio colectivo - que contiene las disposiciones generales, señaladamente las cláusulas obligatorias indicadas en el artículo L. 133-3, aplicables a todas las categorías profesionales de la rama de actividadno determina las condiciones de trabajo propias, sea de aquella categoría que agrupa la fracción numérica más débil de los trabajadores de la rama de actividad interesada, sea de colectivos, particulares sometidos a condiciones de trabajo especiales, el Ministro de Trabajo puede, no obstante, proceder a su extensión por resolución, a condición de que el informe motivado favorable de la comisión superior de convenios colectivos haya sido emitido sin oposición (art. 133-12, 2. ${ }^{\circ}$ ). Sucede lo mismo cuando ha sido imposible celebrar un convenio colectivo para el conjunto de las categorías profesionales y un convenio colectivo - $\mathrm{O}$ un anexo- afecta únicamente a una o varias de estas categorías (art. L. 133-12, 5. ${ }^{\circ}$ ).

La iniciativa pertenece al Ministerio de Trabajo y a los sindicatos y organizaciones patronales más representativas. Una petición conjunta de empleadores y trabajadores no es necesaria (art. L. 133-1, párrafo 1).

La extensión se realiza por una resolución ministerial publicada en el Diario Oficial, acompañada del texto del C.C.T. (art. 133-17).

Una extensión puede tener lugar por resolución prelectoral para las actas adicionales a los convenios colectivos departamentales previamente extendidos por el ministro del ramo y referidos exclusivamente a la fijación del salario de los trabajadores de las profesiones agrícolas. Es necesario que las administraciones y las organizaciones de empleadores y sindicatos miembros de la comisión superior de convenios colectivos - sección especializada-, en un plazo de dos meses, no hayan manifestado oposición a la extensión considerada (art. L. 133-11, párrafo 2 y R. 133-2). 
La extensión no puede resultar del cumplimiento del convenio por algunos empleadores. El hecho de que las disposiciones de un estatuto colectivo sean generalmente aplicables en la profesión no constituye un uso a imponer a una empresa que no haya sido parte en el acuerdo colectivo.

En orden a los efectos de la cuestión analizada hay que distinguir la extensión «clásica» y la extensión «transferencia».

\section{A) Extensión «clásica»}

Esta hace obligatorio el Convenio para todos los empleadores y trabajadores de la región y de la profesión comprendidos en el ámbito de aplicación de este convenio. Simple extensión del ámbito personal de aplicación. El Convenio deviene aplicable a los empleadores y trabajadores siguientes: los que no estaban sometidos a algún convenio; los que estaban sometidos a convenios colectivos firmados por organizaciones no representativas; los que, en fin, por su dimisión de los grupos firmantes habían podido sustraerse así a las obligaciones del convenio. El convenio extendido es pues aplicable a todas las empresas situadas en el campo de aplicación determinado por el mismo, pero no es aplicable a una empresa situada en otra región o cuya actividad le es extraña.

\section{B) Extensión «transferencia»}

Puede ser geográfica o profesional.

En caso de ausencia o falta de organizaciones sindicales de trabajadores o de empleadores que se traduzca en una imposibilidad persistente de concertar un convenio colectivo en una rama de actividad y para un sector geográfico determinados, el Ministro de Trabajo puede, a petición de una de las organizaciones más representativas de los trabajadores o de los empleadores, declarar obligatoria por resolución en esta rama de este sector un convenio colectivo ya extendido a la misma rama para un sector geográfico diferente (art. L. 133-13, párrafo 1). Puede también declarar obligatoria las actas adicionales de este convenio que han sido, las mismas, extendidas (art. L. 133-13, párrafo 2). Es necesario un sector análogo, desde el punto de vista de las condiciones económicas, a aquél en el cual los convenios o actas adicionales se declaran obligatorias (art. L 133-13, párrafo 3). La resolución se adopta en las condiciones indicadas. No puede producirse más que después de informe motivado favorable de la comisión superior de convenios colectivos, emitido sin oposición (art. L. 133-14, párrafo 1), y consulta de 
las organizaciones más representativas de los trabajadores y de los empleadores de la rama de actividad del sector geográfico interesado, o en su defecto, cubriendo la rama de actividad y el sector geográfico interesados (art. 133-14, párrafo 2). La resolución de extensión caduca si el convenio que hacía obligatorio es denunciado o incluso si se pone fin a su extensión (art. 133-15, párrafo 1). Puede ser derogada en las formas en que se produjo si aparece que no responde ya a la situación de la rama y del sector a que se refiere (párrafo 2). En fin, si un convenio susceptible de extensión se celebra ulteriormente para esta rama y este sector, la resolución de extensión de este convenio lleva consigo la derogación de la resolución adoptada a título del artículo L. 133-13 (art. L. 133-15, párrafo 3).

La extensión «transferencia» profesional (art. L. 133-13, párrafo 4) permite al Ministro de Trabajo extender dentro de una rama de actividad, a un sector determinado, un convenio colectivo ya extendido a otro sector profesional de esta rama de actividad, así como las actas adicionales de este convenio que han sido extendidas (art. L. 133-13, párrafo 4).

Debe destacar que por diversas razones matizadas por la doctrina, la extensión «transferencia» se utiliza muy poco.

\section{C) Duración y cesación}

La extensión de los efectos y de las sanciones del convenio colectivo se hace para la duración y en las condiciones que prevé dicho convenio (art. L. 133-10, párrafo 2). Cuando el Convenio cesa de estar en vigor como consecuencia de denuncia o de no renovación, la resolución de extensión pierde su efecto (art. L. 133-18, párrafo 1).

A petición de una de las partes firmantes o por propia iniciativa, el Ministro de Trabajo puede, después de informe motivado de la comisión superior de convenios colectivos, revocar la resolución con vistas a poner fin a la extensión del convenio colectivo o de algunas de sus disposiciones. Esta retirada puede producirse cuando aparece que el convenio o las disposiciones consideradas no responden ya a la situación de la rama de actividad en la región considerada (art. L. 133-18, párrafo 2). Esta resolución debe ser publicada en el Diario Oficial.

\section{b) El caso alemán}

En la República Federal alemana, para que el Ministerio Federal de Trabajo y Asuntos Sociales pueda proceder a la extensión se precisa la solicitud por una de las partes del convenio y la conformidad de una 
comisión integrada paritariamente concurriendo además que los empleados legados por el convenio ocupen como mínimo un 50\% de los trabajadores afectados, que existan razones de interés público, entre ellas la existencia de una situación laboral abiertamente inferior a la del convenio a lo que quizás pueda referirse la Ley española, o que lo exija un estado de emergencia de carácter social. A ello se añade la posibilidad de que los interesados y las autoridades laborales puedan exponer su punto de vista y manifestarse en un debate público.

La determinación legal de las condiciones mínimas de trabajo en caso de no existir Convenio colectivo, en el Derecho alemán se resuelve teniendo en cuenta que si en determinados sectores económicos o en determinadas empresas no se han celebrado convenios colectivos, por no contar los sindicatos con fuerza suficiente para ello, es posible fijar en determinadas circunstancias condiciones estatales mínimas de trabajo. Para ello es preciso:

- Que no existan sindicatos o confederaciones de empresarios para el sector económico o para la naturaleza del empleo, o bien que sólo comprendan una minoría de trabajadores o de empresarios.

- Que se considere necesaria la fijación de condiciones mínimas de trabajo para satisfacer las necesidades sociales y económicas de los trabajadores.

- Que no se haya implantado una reglamentación sobre remuneraciones o de otras condiciones de trabajo a través de un convenio colectivo declarado vinculante con carácter general.

Además de esta autorización general, la Ley sobre fijación de Condiciones Mínimas de Trabajo contiene numerosas disposiciones de procedimiento para garantizar a los empresarios y a los trabajadores su participación en la elaboración de las normas mínimas estatales. Al parecer no se ha recurrido todavía ni una sola vez a esa posibilidad, pese a los casi 40 años transcurridos desde que se dictó la ley. De ahí cabe deducir que no se ha presentado ocasión alguna para la aplicación de la misma; pero, si se tiene en cuenta, por ejemplo, que la Federación de Armadores Alemanes declaró ya en el año 1972 no poder celebrar un convenio colectivo y que las condiciones laborales de este sector figuraban entre las peores, se hubiera podido recurrir perfectamente a la aplicación de esa ley, lo que según Wolfgang Dáubler ${ }^{17}$ no acaeció.

17 Derecho del Trabajo. Editorial: Ministerio de Trabajo y Seguridad Social, p. 226. 


\section{c) El caso italiano}

En el caso italiano conviene resaltar que tal y como ha destacado el profesor Giugni ${ }^{18}$, la jurisprudencia del Tribunal de Casación ha admitido, en efecto, que la autonomía colectiva puede derogar in peius un contrato colectivo corporativo. Esta jurisprudencia, sobre la base de la necesaria adaptación de la norma colectiva a la evolución económicosocial del país, ha llegado a reconocer a la autonomía colectiva (bien que en el ámbito privatístico y a través de una interpretación en algunos casos realmente «integradora» de la Ley) la facultad de desviarse de las instituciones previstas en los contratos colectivos corporativos, introduciendo modificaciones incluso de naturaleza peyorativa.

\section{Análisis jurisprudencial}

En cuanto al análisis jurisprudencial del tema examinado merece destacar la doctrina que a continuación se recoge siguiendo a tal efecto el criterio del Ilustre Magistrado del Tribunal Supremo Excmo. Sr. Marín Correa ${ }^{19}$.

Cuando el artículo 83.1 ETT preceptúa que los Convenios colectivos tendrán el ámbito de aplicación que las partes acuerde, no desconoce las normas de los artículos 87 y 88 sobre la legitimación para negociar y del artículo 89.3 sobre la necesaria concurrencia de voluntades. Por tanto, el aludido artículo 83.1 debe leerse en el sentido de que los Convenios colectivos tendrán el ámbito de aplicación que las partes acuerden, dentro del ámbito de representación ostentada por los negociadores.

Como a ello se une la denominada «impermeabilidad» del ámbito de cada Convenio, ha resultado necesario lo dispuesto en el artículo 92 del propio estatuto para que pueda intercambiarse un Convenio colectivo de determinada unidad de negociación hasta el ámbito de otra de estas unidades. Las condiciones y los requisitos de tal adhesión, o en su caso, de la extensión, acordada por el Ministerio de Trabajo, no parecen consentir que se deje a voluntad de una de las partes del contrato individual de trabajo, la elección del Convenio colectivo aplicable, aunque sea únicamente entre dos de distinto ámbito territorial, pero para la misma actividad.

18 Derecho Sindical. Ministerio de Trabajo y Seguridad Social. Servicio Publicaciones Madrid, p. 163.

${ }^{19}$ El Convenio no estatutario y el riesgo de discriminación. Autor: José María Marín Correa. Comentario a la Sentencia del Tribunal Superior de Justicia del País Vasco de 1 de septiembre de 1993. Editorial: Actualidad Laboral n. ${ }^{\circ}$ 5/31 enero-6 febrero 1994, p. 315. 
Cuando una empresa radica en una provincia, pero tiene centros de trabajo en otra, se ve sometida al Convenio colectivo que le resulte aplicable atendidos los parámetros comunes para determinar el ámbito de aplicación de cada Convenio: actividad y localización geográfica. Sería inútil empeño intentar, en el supuesto aquí contemplado, que se excluyera la aplicación del Convenio colectivo de Vizcaya y del Convenio colectivo de Guipúzcoa, para someterse al Convenio colectivo de la actividad de que se trata y de otro ámbito provincial, porque la voluntad individual no puede prevalecer, frente a la eficacia general de los Convenios, arriba aludida.

Pero es que tampoco parece que la Ley consienta que por Convenio colectivo se confiera a la voluntad unilateral de una de las partes del contrato la exclusión de la aplicación del Convenio colectivo que corresponda, para someterse a otro, en cuyo ámbito no se está. Si por el lugar de prestación de los servicios resultaba de obligada aplicación el Convenio colectivo de Guipúzcoa, bien aplicado está. Si por la radicalidad de la empresa en Vizcaya, el Convenio colectivo aplicable es el de esta provincia, la aplicación del de Guipúzcoa, deberá haber seguido los trámites del arriba mencionado artículo 92 del estatuto. A mayor abundamiento los antecedentes de hecho de la sentencia y los hechos probados, no modificados, no aparece que el trabajador hubiera ejercitado opción en favor de la sustitución del Convenio de Vizcaya por el de Guipúzcoa.

De ahí que la sentencia recurrida funde la decisión no sólo en esa opción que se entiende conferida al trabajador individual, sino que se apoya también en que el Convenio de Guipúzcoa previene que sus cláusulas regulen la relación laboral de los trabajadores de empresas dedicadas a la construcción «y que realicen su actividad dentro del término de la provincia de Guipúzcoa», expansión de su ámbito que pudiera no tener la necesaria correspondencia en los requisitos de legitimación para negociar y de voluntad para convenir de los también citados artículo 88 y 89. En un ejemplo de escuela, el Convenio colectivo de Guipúzcoa podría haber sido negociado por la asociación constituida por dos, hipotéticamente, únicas empresas de la actividad, radicadas en dicha provincia, y aplicarse después a todas las empresas de la construcción, radicadas fuera de la misma, no representadas en la negociación; pero que circunstancialmente desarrollaran su actividad en la reiterada provincia.

Como la empresa no entendió ser «tercero» para impugnar el precepto del Convenio de Guipúzcoa, que la sujetaba a sus normas, debió cumplirle al desarrollar una actividad en dicha provincia, y su omisión le ha acarreado la responsabilidad, directa y no sustituida, de la mejora de prestación reclamada. 
La cuestión se centra en torno al Convenio colectivo y en particular a los ámbitos territorial y subjetivo de aplicación analizando la extensión por disposición expresa de otro convenio colectivo de ámbito territorial distinto y su eficacia en materia de Seguridad Social vía mejora voluntaria de prestaciones pactada en Convenio colectivo cuando la póliza de seguro resulta insuficiente y por ello se hace preciso examinar la responsabilidad de la empresa.

La citada cuestión fue examinada por el T.S.J. del País Vasco (Sala de lo Social). Sentencia, 11 de febrero de 1997. P: Sra. Hernández Vitoria (R. ${ }^{\circ}$ 962/96).

El trabajador demandaba el pago de una cantidad determinada, como mejora de la prestación correspondiente a la invalidez permanente que le había sido reconocida. Prestaba sus servicios a una empresa radicada en Vizcaya; pero lo hacía en un centro de trabajo situado en Guipúzcoa, por lo que apoya su pretensión en el Convenio colectivo de la provincia donde trabajaba, e indirectamente en el de la sede de la empresa, por previsión literal de éste. El Juzgado de instancia absuelve de la pretensión porque entiende que no es aplicable el Convenio colectivo de Guipúzcoa.

Como señaló Marín Correa la Sala de lo Social del Tribunal Superior de Justicia del País Vasco ${ }^{20}$ estima el recurso del trabajador para: a) Declarar la eficacia de la facultad que reconoce el Convenio colectivo de Vizcaya a los trabajadores de las empresas radicadas en esta provincia, que presten sus servicios en centros de trabajo situados en la provincia de Guipúzcoa, en orden a optar por la aplicación del Convenio colectivo de la actividad en esta provincia; b) reconoce el derecho del trabajador recurrente a que, en aplicación del Convenio colectivo en Guipúzcoa, ser mejorado en la prestación de su invalidez permanente con los 6.000.000 de pesetas establecidos en dicho Convenio; c) condena a la empresa a satisfacer dicha mejora; y d) no sustituya esta obligación por la de la compañía aseguradora con quien estableció póliza la empresa, pues esta cobertura se limitó a las previsiones del Convenio colectivo de Vizcaya, sin asumir las obligaciones establecidas por el Convenio colectivo de Guipúzcoa.

En consecuencia con lo anterior, queda centrada la quaestio litis en la determinación de cuál es el convenio que resulta aplicable al trabajador de acuerdo con el ámbito territorial que uno y otro tienen establecido.

20 Una forma extralegal de extensión del Convenio colectivo. Autor: José M. ${ }^{a}$ Marín Correa. Comentario a la Sentencia del Tribunal Superior de Justicia del País Vasco, de 11 de febrero de 1997. Ponente: Sra. Hernández Vitoria. Editorial: Actualidad Laboral, n. ${ }^{\circ}$ 17/7-13 abril, 1997, p. 903. 
El convenio colectivo de construcción y obras públicas de la provincia de Guipúzcoa define dicho ámbito territorial en los siguientes términos: «Este convenio obliga en la provincia de Guipúzcoa a las empresas que dediquen su actividad a la construcción y obras públicas y a todo el personal que trabaja a su servicio, a excepción del que desempeñe cargos de alta dirección o alto consejo» (art. 1).

Por su parte, el artículo 1, apartado B, del convenio colectivo para la construcción de la provincia de Vizcaya, al delimitar su ámbito territorial, dispone que, «El presente convenio será de ámbito provincial, y se extenderá a la provincia de Vizcaya, quedando incluidos en el mismo todos los centros de trabajo a que se refiere su ámbito funcional, y que se hallen emplazados dentro de esta provincia. Los trabajadores que sean trasladados desde la provincia de Vizcaya a otra cualquiera se acogerán, si así lo consideran oportuno, al convenio más beneficioso de entre los concurrentes, en cómputo anual vigente en el momento del traslado, siendo tal cómputo de aplicación mientras permanezca en esta situación, esto es, fuera de la provincia de Vizcaya».

Dadas una y otra regulación, la sentencia tenía la obligación de resolver si una situación como la examinada —en la que una empresa con sede social en Vizcaya contrata con Guipúzcoa a un trabajador con el fin de que éste desarrolle su actividad en esta última provincia- se encuentra comprendida en el ámbito de aplicación territorial del convenio colectivo de la construcción y obras públicas de Vizcaya, como entiende la sentencia de instancia o, por contra, queda incluida en el del convenio colectivo de Guipúzcoa.

La sentencia se inclina hacia esta última solución, en razón a los siguientes argumentos:

1. $\left.{ }^{\circ}\right)$ Como señala el artículo $1 \mathrm{~b}$ ) del Convenio colectivo de la construcción para Vizcaya, quedan comprendidos dentro de su ámbito de aplicación todos los centros de trabajo a los que se refiere su ámbito funcional que se hallen emplazados dentro de esta provincia, de tal manera que, siguiendo las reglas de interpretación literal de las normas jurídicas que se recogen en el artículo 3.1 CC, se advierte la necesidad de que el centro de trabajo al que se pretende sea de aplicación el convenio colectivo de referencia tenga que encontrarse dentro del territorio al que se extiende la provincia de Vizcaya, lo que no sucedía en el caso examinado, puesto que los trabajos se realizaban en la provincia de Guipúzcoa. Por tanto, no puede regir el Convenio colectivo de Vizcaya, puesto que faltan los presupuestos que condicionan la aplicación de la normativa por la que se fija el ámbito territorial del mismo. 
2. $\left.{ }^{\circ}\right)$ El párrafo por el que el repetido Convenio de Vizcaya regula la normativa a la que deberán quedar sujetos los trabajadores en caso de traslados debe entenderse en el sentido siguiente: cuando un trabajador desempeña sus servicios para una empresa en la provincia de Vizcaya y es asignado con carácter temporal a una localidad diferente radicada en otra provincia, tendrá la opción de acogerse al convenio que le resulte más beneficioso. Pero si lo que ha sucedido es que desde un primer momento, y durante todo el tiempo de prestación de sus servicios, el trabajador ha estado destinado en una localidad radicada fuera de Vizcaya, no cabe aplicar la normativa que el convenio colectivo de esta provincia establece en casos de traslados, sino que, en tal supuesto, el fuero por el que se regirá la concreción del ámbito territorial del convenio vendrá dado por la lex loci laboris, es decir, el lugar de realización habitual de los servicios.

De sostenerse otra postura se darían paradojas tales como que la empresa demandada contratará a un trabajador en una provincia muy lejana, como pudiera ser la de Sevilla, para realizar trabajos en esa misma localidad y pretendiera aplicarle el convenio colectivo de la construcción de Vizcaya sobre la única base de que la sede social de la contratante radicaba en esta última provincia.

$\left.3^{\circ}{ }^{\circ}\right)$ Todo ello lleva a la exclusión del convenio de Vizcaya y remite al convenio de Guipúzcoa, puesto que su ámbito de aplicación territorial sólo queda condicionado por la concurrencia de dos presupuestos - que se trate de empresas dedicadas a construcción u obras públicas y que realicen su actividad dentro del término de la provincia de Guipúzcoa-.

Por consiguiente, si el propio convenio de Guipúzcoa determina que sus previsiones regulan la relación laboral de todos los trabajadores (con las solas excepciones de cargos de alta dirección o alto consejo) al servicio de las empresas que reúnan las circunstancias antes examinadas, hay que concluir que el convenio de Guipúzcoa es aplicable, como resulta de lo dispuesto en el artículo 83.1 ETT, según el cual los convenios colectivos tendrán el ámbito de aplicación que las partes acuerden.

$\left.4^{\circ}{ }^{\circ}\right)$ En función de lo anterior, no se comparte el argumento contrario según el cual la aplicación del convenio colectivo de Guipúzcoa a una empresa queda supeditada a que la misma tenga su sede social en esa provincia, puesto que ya hemos visto que el artículo 1 de dicha norma no lo precisa.

De igual modo, tampoco cabe admitir que la aplicación del convenio de Guipúzcoa pudiera conllevar una situación de insegu- 
ridad jurídica para la empresa recurrida (en el sentido de que la regulación de la relación laboral por la que se regirían los operarios a su servicio variaría en función de las diversas provincias en las que tuvieran que realizar obras) que conduciría a la exclusión de todo convenio colectivo distinto al de Vizcaya, puesto que la ley ya arbitra mecanismos suficientes con el fin de acomodar la totalidad de las relaciones jurídicas de los trabajadores pertenecientes a una empresa a una misma fuente convencional (supuesto del convenio de empresa) y, en todo caso, al margen de estos argumentos, resulta incuestionable que una vez que se constata que el convenio que resulta de aplicación es el de Guipúzcoa, deviene obligada la observancia de sus preceptos.

Ciertamente, una vez incluida una relación laboral en el ámbito de aplicación de un convenio, las previsiones de este último resultan imperativas, como recoge el artículo 82.3 ETT y recalca la sentencia de casación para unificación de doctrina de fecha 4 de mayo de 1994 (R. 7725), al manifestar que «las sentencias también de esta Sala del Tribunal Supremo, dictadas en fechas más recientes, de 24 de enero de 1992 (R. 1992, 69) y 29 abril 1993 (R. 1993, 3381) manifiestan que reiterada la jurisprudencia ha sentado que la garantía constitucional de la fuerza vinculante de los convenios colectivos implica la atribución a los mismos de una eficacia jurídica en virtud de la cual el contenido normativo de aquéllos se impone a las relaciones de trabajo incluidas en sus ámbitos de aplicación de manera automática (sentencia de Pleno del Tribunal Constitucional 58/85, de 30 de abril».

Otra cuestión de no menor importancia viene representada en punto al régimen aplicable al Convenio Colectivo Extraestatutario pues el límite de su eficacia directa a empresa y trabajadores representados en la negociación no lleva a valorar la posible solicitud del trabajador individual y la posibilidad de que ello obligue a la empresa.

El tema fue objeto de análisis por la Sentencia del T.S.J. del País Vasco (Sala de lo Social). Sentencia, 1 de septiembre de 1993.

En torno a la cuestión referida se señala lo siguiente: a) No es discriminatorio el límite de eficacia directa de un Convenio colectivo adoptado sin los requisitos precisos para que sea obligatorio erga omnes. b) Está excluida la discriminación porque se tiene por existente una oferta empresarial para que cualquier otro trabajador acepte la aplicación del Pacto, c) la representatividad institucional del Sindicato se 
limita aquí a los trabajadores afiliados, pues deriva del acto de afiliación, y d) hay un ámbito de aplicación constituido por la propia empresa, dentro de la cual se encuentran sus trabajadores, cuya solicitud de aplicación obliga a la empresa, y da lugar a la extensión del Convenio.

La cuestión está radicada en si cabe jurídicamente que la individual aceptación implícitamente derivada de la suscripción de la petición de abono del complemento específico, del representado por un Sindicato no signante del acuerdo que individualmente postula se aplique un afiliado al mismo, deviene en exigible para el empleador, o puede éste ampararse en el ámbito de aplicación del pacto como causa denegatoria de la solicitud del trabajador. En el primer caso la solicitud implicaría el nacimiento del derecho del postulante de forma ineludible para el empresario. En el segundo sería un requisito pero no constitutivo de la obligación empresarial pues ésta dependería del ámbito personal en el que consiente. Se vuelve así a la eficacia normativa o convencional del pacto alcanzado al margen de las previsiones legalmente establecidas en el Estatuto de los Trabajadores.

Tal cuestión queda obviada si se atiene el aplicador de la norma a la determinación del ámbito personal de aplicación del acuerdo, con independencia de la eficacia del mismo. Primeramente habrá de determinarse a quién se aplica y sólo después con qué fuerza vinculante.

De lo considerado anteriormente se desprende que el Acuerdo en cuestión carece de fuerza normativa, al ser extraestatutario, y que tiene eficacia contractual entre los firmantes, que no representan al demandante, por lo que en principio, en aplicación del artículo 1.257 del Código Civil no le sería aplicable al mismo.

Pero como las partes que los suscriben y entre ellos la patronal configuran un ámbito personal de aplicación del Acuerdo, en su artículo 2, en el que se incluye el actor, éste está incurso en el ámbito de eficacia personal del pacto, constituyendo su contenido una evidente oferta, que una vez aceptada por aquel a quien se dirige, perfecciona un contrato, por mor de los artículos 1.254 y 1.258 del Código Civil, ya que los signantes del mismo no limitaron el ámbito aplicativo de lo acordado a las representaciones que lo convinieron, abriéndose así la posibilidad de su aplicación a aquellos trabajadores no representados por los Sindicatos firmantes que expresamente acepten la oferta empresarial, que se configura a modo de estipulación en favor de terceros - los trabajadores afiliados a cualquier sindicato no presentes en la negociación o simplemente independientes sindicalmente.

A la vista por tanto de la expresa solicitud del trabajador acogiéndose a la regulación del Acuerdo, es claro que éste aceptó se le aplique el mismo, por lo que de su aceptación se deduce la eficacia 
contractual del mismo respecto del empresario y el concreto demandante de forma directa — no en razón a fuerza normativa vinculante del Convenio ni en atención a la representación de los sindicatos firmantes-y por tanto su derecho subjetivo por el que acciona, razón que provoca la estimación del motivo de recurso y la revocación de la sentencia dictada.

El propio Marín Correa (comentario citado) analiza una cuestión capital en torno a esta sentencia. Tal materia no es otra que la del convenio no estatutario y el riesgo de discriminación. Dicho autor señala que la situación originada por la empresa es inicialmente de discriminación, aunque sea salvada por el pronunciamiento judicial. Porque, si se concluye que la solicitud del trabajador significa su adhesión individual al Pacto colectivo de eficacia limitada, la negativa de la empresa estaba aplicando su criterio discriminatorio, derivado, en definitiva, de la afiliación a «otro» Sindicato, o de la simple «no» afiliación.

Deben, pues, señalarse con claridad tres espacios temporales, que servirán para no incurrir en "peticiones de principio», sino actuar la lógica de la negociación colectiva laboral, sin eficacia erga omnes. Estos tres momentos son: a) El establecimiento del pacto colectivo con eficacia limitada, cuya aplicación sólo será exigible por quien estuviera representado en la negociación; b) la adhesión -individual o colectiva- cuya posibilidad debe quedar abierta sin limitación, so pena de incurrir en discriminación; y c) la aplicación al adherido, por la misma eficacia contractual reconocida respecto de quien negoció, y aquí nacida de una nueva negociación (se insiste individual o colectiva) concluida con concordancia de voluntades. Pero, bien sabido, que la voluntad de la empresa no puede negarse, pues la negativa constituirá discriminación.

La Sentencia mencionada, según aquel autor, salva de la discriminación a la empresa, porque afirma o tiene por sobreentendida, la actitud abierta a la adhesión; después afirma que la solicitud del trabajador existía y, al tener por existente aquella voluntad de la demandada, concluye que se dio lugar al contrato de adhesión, y que el Pacto resulta eficaz entre este trabajador adherido y su empresario.

Lo difícil es excluir la discriminación, cuando se parte de una negativa de aplicación del Pacto, y de una absolución de la demanda que la reclamaba. Para Marín Correa (comentario citado) se salva la situación entendiendo que la negativa se refería únicamente al tercer momento de los arriba señalados, o sea, a la realidad del contrato individual, pero no a su posibilidad.

Ante la inexistencia de un Convenio provincial aplicable a un sector concreto cabe plantearse cuál será el Convenio que se le aplique. 
En tal sentido el profesor Gete Castrillo ${ }^{21}$ señala que sin perjuicio de la necesaria exégesis que haya de hacerse para averiguar cuál sea, si lo hay, el convenio aplicable al concreto supuesto de una empresa en cuya provincia no existe convenio de sector y, por supuesto, carece la propia empresa de Convenio propio, parece de todo punto conveniente dejar sentado que la negociación colectiva es un derecho constitucional (arts. 7, 28 y 37 de la Constitución Española), reconocido a los representantes de los trabajadores y a los representantes de los empresarios cuyo ejercicio autónomo es libre, por lo que no ha de buscarse nunca un pretendida y uniforme regulación convencional para un sector determinado. Como muy bien se expresa el artículo 82.1 del Estatuto de los Trabajadores, el Convenio colectivo es el resultado de una negociación libre y autónoma de las representaciones de trabajadores y empresarios.

Ello implica que el Convenio es norma sectorial no concebida para una regulación general ni uniforme, sino para grupos o colectivos muy definidos en la propia norma o convenio.

Vano resultará, pues, el empeño por encontrar un Convenio aplicable si el colectivo al que se le pretende aplicar no está, de algún modo, representado o afectado por el complejo entramado legal de lo que el Estatuto de los Trabajadores entiende por unidades de contratación, y ámbito de aplicación.

No tiene por qué coincidir el ámbito funcional ni el subjetivo de un convenio con el que tuviera una Reglamentación de Trabajo u Ordenanza Laboral. Así lo reconoce la jurisprudencia, para la que no es posible pretender extender el ámbito de un Convenio al de una Reglamentación en razón, precisamente, a la libertad que las partes tienen de fijar la unidad de contratación, pudiendo un convenio afectar sólo a una empresa o varias de las comprendidas en el ámbito funcional de una Reglamentación (Sentencia del Tribunal Central de Trabajo, de 3 de diciembre de 1986).

Ello no obsta para que en un sistema de negociación colectiva asentada y maduro se vayan consolidando unidades típicas de negociación, con su legitimación directa o ampliada para negociar y de cuyo ejercicio de la capacidad negociadora surjan convenios eficaces en unos ámbitos menores o mayores ya consolidados, siendo lo importante el que tales unidades sean las propias o adecuadas en razón a la coincidencia interna de intereses laborales compartidos entre quienes las integran, de modo que la norma sectorial que resulte contenga una regulación uniforme y coherente para el sector afectado. O como la jurisprudencia

21 Ante la inexistencia de un Convenio provincial cuál será el Convenio que se le aplique. Pedro Gete Castrillo. Editorial: La Ley-Actualidad, 1998. 7/1998. 
afirma, es lo importante que el convenio tenga un ámbito acorde con la naturaleza de las cosas y no sea artificioso.

Ante la duda sobre qué convenio se aplique, será acudir al principio de especificidad (Sentencia del Tribunal Central de Trabajo, de 25 de enero de 1984) y buscar aquel convenio que resulte adecuado según la actividad de la empresa, pues es dicha actividad, tratándose de convenios de sector, no de empresa, el factor determinante de la inclusión en el campo de aplicación de un convenio en concreto.

En virtud de la libertad de determinación del ámbito de que gozan las partes ex artículo 83.1 del Estatuto de los Trabajadores, cada convenio tendrá aplicación para quienes las partes negociadoras hayan prefijado, ya que son ellas quienes pueden concretar la unidad de negociación adecuada a las características y necesidades que les sean propias (Sentencias del Tribunal Central de Trabajo, de 21 de junio de 1983 y 26 de marzo de 1987). Sin que ello pueda obviar un requisito esencial, cual es el de que para que un convenio se aplique a una empresa ésta ha de considerarse incluida en la unidad de contratación del convenio de referencia (Sentencia del Tribunal Central de Trabajo, 4 de mayo de 1987).

Salvadas esa libertad de autoconfigurar los ámbitos de un convenio y su obligada adecuación a los intereses laborales homogéneos y la no necesaria coincidencia con el ámbito de las viejas Reglamentaciones de Trabajo, hay que tener presente la posibilidad del fenómeno de la extensión o de la adhesión a un convenio preexistente.

Mediante un acuerdo de adhesión de los representantes de trabajadores y del de los empresarios de que se trate, en virtud de lo previsto en el artículo 92.1 del Estatuto de los Trabajadores, las partes legitimadas para negociar pueden adherirse a un convenio preexistente, en su totalidad y siempre que no estuvieran afectadas por otro convenio, por cuando la concurrencia está vedada por el artículo 84 y el propio artículo 92.1 del Estatuto de los Trabajadores.

Igualmente, ante la inexistencia de convenio en un ámbito o unidad de negociación concreto y en base a las dificultades existentes para que en unas o varias empresas exista convenio, la Autoridad Laboral puede producir un acto administrativo de extensión de otro convenio colectivo preexistente que guarde una relación de adecuación y similitud con los intereses laborales en juego y una vez oídas las representaciones de las partes, tal como previene el propio y citado artículo 92.2 del Estatuto de los Trabajadores desarrollado por el Real Decreto 572/1982, de 5 de marzo, sobre procedimiento de extensión de convenios colectivos.

Por lo demás, también existe la previsión normativa de la disposición adicional 1. a del Estatuto de los Trabajadores, en virtud de la cual, si no pudiera ponerse en práctica el procedimiento extensivo del artícu- 
lo 92.2, el Gobierno, a propuesta del Ministerio de Trabajo y previas las pertinentes consultas a sindicatos y asociaciones empresariales, puede dictar la regulación de condiciones de trabajo para una rama de actividad allí donde, funcional o territorialmente no exista convenio colectivo.

Se hace preciso igualmente examinar un fenómeno que viene a confundirse con la extensión del Convenio en cuanto que pueda suponer la aplicación a un ámbito concreto de un convenio no previsto inicialmente por tales supuestos. Ello acaece de ordinario en el campo de las fusiones y segregaciones de empresas o unidades de negocio ${ }^{22}$.

El cambio de titularidad es un concepto de amplitud tal que comprende cualesquiera tipos de transmisión, todos los cuales imponen la continuidad de los contratos de trabajo e implican la subrogación empresarial; y en este sentido cabe incluir en el supuesto de hecho del artículo 44.1 la fusión de Sociedades.

En cuanto a las obligaciones derivadas de esta sucesión de empresa el propio artículo 44.1 señala la del cedente y en su defecto del cesionario de notificar el cambio a los representantes del personal de la empresa o centro de trabajo objeto de la cesión. La omisión de esta obligación, dice Alonso Olea (obra citada p. 752), no afecta a la validez de la transmisión ni impide a ésta surtir sus efectos, siendo prueba de ello el que pueda hacerla el cesionario en defecto del cedente lo que implica cesión ya realizada. Ello indica que la finalidad principal sea identificar al nuevo empresario.

$\mathrm{Ni}$ siquiera el viejo principio de unidad de empresa consagrado en el artículo 5 de la Ley de 16 de octubre de 1942 tenía carácter absoluto. El profesor Alonso Olea consideró ya desde un principio como una excepción al mismo el supuesto de subrogación.

Con mucha más razón ahora que dicho principio es incompatible con el actual marco normativo constituido por el artículo 37.1 de la Constitución Española, que garantiza el derecho a la negociación colectiva, y el artículo 83.1 del Estatuto de los Trabajadores, que ampara cualquier tipo de unidad negocial, lo que conlleva la posibilidad de coexistencia dentro de una empresa de varios convenios parciales. Y si esta posibilidad cabe dentro de una empresa más lógica será que quepa el respeto del convenio existente para los centros que sean objeto de una subrogación.

A tal efecto cabe recordar que el Tribunal Central de Trabajo en Sentencia, de 15 de enero de 1986, señaló que «El convenio de centro

22 Consecuencias de la fusión de Sociedades Anónimas. Pedro Gete Castrillo. Editorial: La Ley-Actualidad, 1998. 117/1998. 
negociado en su día por los actores debe subsistir durante el plazo de vigencia respecto a su ámbito propio sin más modificaciones que la sustitución del anterior empleador por el nuevo...».

Por otro lado, no cabe la adhesión del artículo 92 del Estatuto de los Trabajadores, pues la primera limitación para que pueda tener lugar la adhesión es que el colectivo que pretende adherirse no esté afectado por otro convenio; y ello, según analiza el profesor Alonso Olea, para respetar la regla sobre prohibición de concurrencia de convenio del artículo 84 del Estatuto de los Trabajadores.

Igualmente y en orden a la adhesión a los Convenios extraestatutarios cabe mencionar el contenido de la doctrina de la Audiencia Nacional (Sala de lo Social), que aparece en la Sentencia, 12 de mayo de 1998, y de la que fue ponente el Excmo. Sr. Basterra Montserrat ${ }^{23}$.

En ella se dice que es preciso resaltar que el artículo 92 del Estatuto de los Trabajadores no afecta al caso, pues se refiere a la totalidad de un convenio en vigor, al que pueden adherirse si no están afectados por otro, comunicándolo a la autoridad laboral para registro.

En el mismo sentido merece destacar la sentencia del mismo Tribunal 139/1997, de 5 de diciembre, en referencia al aspecto de la interpretación del silencio una vez dirigida la oferta por la empresa. Dicha sentencia señala que «también el Sindicato accionante podría haber preparado un escrito modelo standard de oposición que sólo requiera la firma de cada trabajador que así lo desease hacer. El Código Civil, en sus artículos $1.255,1.256,1.258,1.274$ y 1.278 establece los contratos, los requisitos esenciales para la validez de los mismos, y el consentimiento necesario para su validez y plena eficacia, deduciéndose palmariamente de estos preceptos que la comunicación dirigida por la empresa a los trabajadores no es contraria a la Ley ni al orden público (art. 1.255), no ha quedado al arbitrio de una sola de las partes (1.256), ha sido perfeccionado por mero consentimiento tácito (1.258), ha habido una causa (1.274) y, finalmente, han concurrido las condiciones esenciales para su validez (1.278), por todo lo cual la decisión de la Sala debe ser negativa respecto de la pretensión».

La doctrina del Tribunal Supremo (Sala de lo Social), recogida en la Sentencia, 30 de octubre de 1995, de la que fue ponente el Excmo. Sr. Martínez Emperador, fija, en orden a la pretendida extensión en los grupos de empresa de los Convenios colectivos, que cuando la direc-

23 Convenio Colectivo Estatutario. Félix de las Cuevas González. Comentario a la Sentencia de la Audiencia Nacional (Sala de lo Social), de 12 de mayo de 1998. Ponente: Sr. Basterra Montserrat. Editorial: La Ley-Actualidad, 1998, 1.535/1998. 
ción del grupo de empresas no fue la que decidió el ámbito de la unidad de negociación la cual ya estaba fijada en anteriores convenios, ni la que determinó el contenido del convenio, el cual resultó de la libre voluntad de las partes que lo negociaron, ni la que designó a los miembros del «banco social», los cuales fueron libremente elegidos por la totalidad de los representantes unitarios existentes en las empresas incluidas en el ámbito de aplicación del convenio, resulta que la no inclusión de otras empresas correspondiente al mismo grupo, la determinación de sus límites fue libremente establecida por las partes que lo negociaron, tal como autoriza el artículo 83.1 del Estatuto de los Trabajadores, siendo de señalar, además, como también declara la Sentencia del Tribunal Supremo, de 27 de abril de 1995, contestando a alegación análoga, que lo que en definitiva persigue la parte recurrente es lograr la extensión del convenio, con olvido de lo que dispone al respecto el artículo 92.2 del Estatuto de los Trabajadores.

Debemos destacar también la doctrina del Tribunal Supremo (Sala de lo Social), recogida en la Sentencia, 23 de septiembre de $1997^{24}$, de la que fue ponente el Excmo. Sr. Fernández López, en relación con la impugnación de los procesos de adhesión.

Dicha doctrina señala que el Acuerdo de Adhesión previsto en el artículo 92.1 ETT en rigor no es sino una modalidad peculiar o forma especial de Convenio colectivo, por lo que el proceso adecuado es el especial regulado en los artículos 161 y ss. LPL, que prevé la posibilidad de que se inicie de oficio por la Administración laboral en el supuesto previsto en el artículo 90.5 ETT.

En orden a las competencias estatales sobre la materia conviene recordar la doctrina del Tribunal Constitucional, recogida en la Sentencia 102/91, de 13 de mayo, de la que fue ponente el Excmo. Sr. Tomás y Valiente (BOE, 18 de junio de 1991).

La Consejería de Trabajo y Seguridad Social del Consejo de Gobierno de Andalucía dictó la resolución, de 5 de diciembre de 1985, extendiendo el Convenio Colectivo Provincial de Oficinas y Despachos de la Provincia de Granada y la Provincia de Sevilla. El Ministerio de Trabajo y Seguridad Social, por resolución, de 19 de enero de 1987, extendió el Convenio Colectivo Provincial de Oficinas y Despachos de la Provincia de Granada a la Provincia de Sevilla. Ambas resoluciones dieron lugar a planteamiento de los conflictos positivos de competencia, respectivamente 533/86 y 993/87. El T.C. declara la competencia de la Comunidad Autónoma Andaluza.

24 Sentencia de la Sala de lo Social del Tribunal Supremo, de 23 de septiembre de 1997. Ponente: Sr. Fernández López. Editorial: La Ley-Actualidad, 1998. 133/1998. 
En base a que una vez constatado que la competencia controvertida en los conflictos acumulados 533/1986 y 993/87 no es otra que la facultad de dictar actos de extensión de convenios colectivos al amparo del artículo 92.2 E.T. y normas reglamentarias de desarrollo, resulta evidente que la cuestión suscitada es igual a la resuelta por la Sentencia de este Tribunal, de 25 de abril de 1991 (conflictos acumulados números 1.208/1985, 1.211/1985, 642/1986 y 280/1987). En esta Sentencia se señaló que el acto de extensión de un convenio colectivo no está incluido en la legislación en materia laboral que el artículo 149.1,7 C.E. reserva al Estado al no aparecer vinculado en modo alguno a «la finalidad del precepto constitucional de mantener una uniformidad en la ordenación jurídica de la materia» (fundamento jurídico 3. ${ }^{\circ}$ ). Por el contrario, el citado acto «pertenece a la esfera de lo ejecutivo» en cuanto que, aparte de no existir, en rigor, creación de una norma, las facultades administrativas que conducen a la extensión del ámbito de la anteriormente existente se encuentran rígidamente precondicionadas por determinados requisitos (fundamento jurídico $4 .^{\circ}$ ).

En consecuencia, y dado que ente las competencias de la Comunidad Autónoma de Andalucía se incluye la ejecución de la legislación del Estado en materia laboral (art. 17.2 E.A.A.), hay que declarar que a ella le corresponde la facultad de extender Convenios colectivos.

La tesis en pugna son, en esta materia y en apretada síntesis, las siguientes: por un lado se sostiene que la facultad de extender convenios colectivos corresponde exclusivamente al Estado, con apoyo en contraposición entre «legislación» y «ejecución» en los términos en que fija el reparto de competencias en la materia laboral el artículo 149.1,7 de la Constitución Española.

En una palabra, el acto de extensión no es un acto de mera ejecución propio de una Administración pública sino que tiene naturaleza reglamentaria; es más el convenio colectivo regular o estatutario es una norma por sí mismo y queda sometido a las reglas competenciales propias de los productos normativos tal y como se recoge en la expresión técnica «legislación».

En fin, esta tesis del carácter normativo reglamentario del acto de extensión se apunta en la STC 17/1986, de 4 de febrero (BOE, de 5 de marzo), en la que, con cierta incongruencia en verdad, se sostuvo, por un lado que la naturaleza del acuerdo administrativo ahora analizado constituía tema de escaso tratamiento científico, y, por otro lado, que la posición mayoritaria de la doctrina española «... parece inclinarse a su consideración como actuación administrativa de carácter reglamentario...», por lo que la sentencia concluía que el acto de extensión de un convenio colectivo regular $« . .$. es un reglamento per relationem a tra- 
vés de las disposiciones establecidas en el convenio...» A mayor abundamiento en esta tesis hubiera podido traerse a colación la STC 35/82, de 14 de junio.

Pero, por otro lado, hubo quienes, como Efrén Borrajo ${ }^{25}$, doctrinalmente entendieron que tal acto de extensión era un «acto administrativo no reglamentario...» (en contra Sala Franco), siendo esta es la tesis que sienta, ahora con firmeza, el Tribunal Constitucional en la sentencia referida.

\section{Bibliografía}

Alonso Olea, M.: Derecho del Trabajo. Editorial Servicio Publicaciones Facultad de Derecho. Universidad Complutense de Madrid. Madrid, 1999.

Alonso Olea, M. y BarReiro, Germán: Comentarios al Estatuto de los Trabajadores. Editorial Civitas. Madrid, 1998.

Montoya, Alfredo y otros: Comentarios al Estatuto de los Trabajadores. Editorial Aranzadi. Madrid, 1995.

Montoya, A.: Derecho del Trabajo. Editorial Tecnos. Madrid, 1995.

Sala Franco, T.: La Negociación Colectiva y los Convenios Colectivos. Ediciones Deusto. Bilbao, 1990.

Iglesias Cabero, M.: Negociación Colectiva. Editorial Colex. Madrid, 1997.

Molero Manglano, C.: Lecciones sobre Convenios Colectivos, Derecho de Huelga y Cierre Patronal. Editorial Ediciones ICAI. Madrid, 1985.

De LA VILLA, L.E. y otros: Instituciones de Derecho del Trabajo. Editorial Centro de Estudios Universitarios. Ramón Areces. Madrid, 1983.

PalomeQue, Carlos: Derecho Sindical Español. Editorial Tecnos. Madrid, 1986.

Roussomano, V.: Principios Generales de Derecho Sindical. Editorial Instituto de Estudios Políticos, p. 216. Madrid, 1977.

Claude Javillier, J.: Derecho del Trabajo. Editorial Instituto de Estudios Laborales y de la Seguridad Social. Madrid, 1982.

DAubleR, Wolfrang: Derecho del Trabajo. Editorial Ministerio de Trabajo y Seguridad Social. Madrid, 1994.

GiUgnI, Gino: Derecho Sindical. Ministerio de Trabajo y Seguridad Social. Servicio Publicaciones Madrid. Madrid, 1983.

Borrajo, Efrén (autor): Naturaleza Administrativa del Acto de Extensión del Convenio Colectivo. Comentario a la Sentencia, de 13 de mayo de 1991. Ponente Sr. Tomás y Valiente. Editorial Actualidad Laboral, n. ${ }^{\circ} 39,21-27$ de octubre de 1991. Madrid, 1992.

MARÍn CORREA, José María (autor): El Convenio no estatutario y el riesgo de discriminación. Comentario a la Sentencia del Tribunal Superior de Justicia del

25 Naturaleza Administrativa del Acto de Extensión del Convenio colectivo. Autor: Efrén Borrajo. Comentario a la Sentencia, de 13 de mayo de 1991. Ponente: Sr. Tomás y Valiente. Editorial: Actualidad Laboral, n. ${ }^{\circ}$ 39, 21-27 de octubre de 1991, p. 2.051. 
País Vasco, de 1 de septiembre de 1993. Editorial Actualidad Laboral, n. ${ }^{\circ}$ 5/31 de enero-6 de febrero de 1994. Madrid.

MARín CorreA, José María (autor): Una forma extralegal de extensión del Convenio Colectivo. Comentario a la Sentencia del Tribunal Superior de Justicia del País vasco, de 11 de febrero de 1997. Ponente Sra. Hernández Vitoria. Editorial Actualidad Laboral, n. ${ }^{\circ}$ 17/7-13 abril, 1997. Madrid.

Gete CAstrillo, Pedro: Ante la inexistencia de un Convenio provincial cuál será el Convenio que se le aplique. Editorial La Ley-Actualidad, 1998. 7/1998. Madrid.

Gete Castrillo, Pedro: Consecuencias de la fusión de Sociedades Anónimas. Editorial La Ley-Actualidad, 1998. 117/1998. Madrid.

De las Cuevas GonzÁlez, Félix: Convenio Colectivo Estatutario. Comentario a la Sentencia de la Audiencia Nacional (Sala de lo Social), de 12 de mayo de 1998. Ponente Sr. Basterra Montserrat. Editorial La Ley-Actualidad, 1998. 1.535/1998. Madrid.

MARTínez EMPERAdor (ponente): Comentarios a la Sentencia de la Sala de lo Social del Tribunal Supremo, de 30 de octubre de 1995. Editorial La Ley-Actualidad, 1998. 216/1996. Madrid.

FERNÁNDEZ LóPEZ (ponente): Comentarios a la Sentencia de la Sala de lo Social del Tribunal Supremo, de 23 de septiembre de 1997. Editorial La Ley-Actualidad, 1998. 133/1998. Madrid. 